\title{
Impacts of wheat bran on the structure of the gluten network as studied through the production of dough and factors affecting gluten network
}

\author{
Nora Abdullah ALFARIS ${ }^{1 *}$ (D), Anil Kumar GUPTA², Danish KHAN ${ }^{2}$, Mahfoozurrahman KHAN ${ }^{3 *}$, \\ Saikh Mohammad WABAIDUR ${ }^{4}$ (D), Jozaa Zaidan ALTAMIMI ${ }^{1}$, Zeid Abdullah ALOTHMAN ${ }^{4}$, \\ Tahany Saleh ALDAYEL ${ }^{1}$
}

\begin{abstract}
Wheat flour with high protein quality is utilized for a wide scope of heated items particularly bread because of the viscoelastic property of the wheat flour that exhibits both viscous and elastic characteristics when undergoing deformation. Wheat contains the gluten framing proteins that structure a viscoelastic. D-glucans is considered as one of the best hydrocolloids for their gelling capacity and ability to impart the viscosity of aqueous solutions. By framing this viscoelastic mixture, permits the air cell to join and opposes its blend. The blending procedure includes the blending of flour and different fixings with water and which is also affects the last item surface. The target of blending is to shape and form the gluten organizes into a viscoelastic, with the capacity to hold joined air. The acid and basic value of $\mathrm{pH}$ is important for every sector such as; food and chemical industries, some important bakery products, and $\mathrm{pH}$ (Biscuits; 7.0-7.2, Baker's yeast bread; 5.3-5.8 and Sourdough bread; 3.8-4.6, etc.). Gluten makes them flexible enough to expand as a little inflatable without damaging the air pocket dividers before the bread is proven. The flavor and crunchy texture of wheat pieces of bread sharpen our appetite and satisfy our basic human cravings for comfort as well as nutrition. At the point, when flour produced using pounding these grains are blended in with water, the two proteins join and structure gluten and without water, gluten isn't shaped. According to its summary article, it tries to clarify how the chemical compatible properties of dough work to make and preserve gluten framing proteins. Wheat bran increased dough stability by raising the farinograph property, enhanced dough elasticity by raising elastic modulus and decreased tan of the dough at all gluten contents, according to viscoelastic profiles. The findings help to understand the mode of action of the modification on wheat bran and the formation of the gluten network.
\end{abstract}

Keywords: blending; wheat bran; dough development; gluten network; bakery product ph; factor affecting gluten network.

Practical Application: Impacts of wheat bran on gluten.

\section{Introduction}

Wheat grain is a result of processing wheat and roller processing produces a spotless partition of the wheat and germ from the endosperm through continuous advances including crushing, sieving, and cleansing advances (Campbell, 2007). The wheat grain contains $2 \%$ bioactive mixes, including numerous nutrients, phenolic mixes, and phytochemicals, inside a solid stringy structure (Shewry, 2009). These phytochemicals are critical in the entire grain of oat (wheat) and incorporate n-3 unsaturated fats, sulfur amino acids, oligosaccharides, lignin, minerals and other components, for example, ferulic corrosive and smaller measures of lignans, etc. (Ahmed, 2014). There are a few fibre fixings accessible to the dough puncher and scientists have evaluated their accessible structures, usefulness and other application in different-different wheat flours and wheat communicates with water and can assimilate a lot of water (Hemdane et al., 2018; Alashbayeva et al., 2021; Khan et al., 2020a). Wheat holds water with an assortment of large scale, smaller scale, and atomic level instruments. All these types of instruments add to water take-up wonders and are considered as an element of wheat grain molecule size (Chaplin, 2003). It also enhances the interaction between dispersed and hydrated gluten-forming proteins by correctly mixing flour through the water before gluten is formed and this process is also known as blending (Sliwinski et al., 2004). In bread making, the grain is hydrated during the blending process and is exposed to the manipulating and hygroscopic powers of different flour segments (Ma et al., 2018; Amirkaveei et al., 2009). Water bounce is moderately pitifully bound through these elements and discharges within the sight of these external forces because stacking and micropores do not contribute to hydration. The impending impact of wheat expansion on bread development can be ascribed to the weakening of different proteins (gluten) (Campbell et al., 2008; Benam et al., 2021). Grain may intrude on gluten advancement by forestalling appropriate contact between different sizes of wheat flour particles. There may be extra negative impacts not abundantly secured by gluten weakening. 
Through the Farinograph analysis, mixture advancement times when more elevated wheat was supplanted with different flours were determined. Wheat's pernicious effect may depend on the form and level of grain applied to the mixture (Ma et al., 2018).

For the most part, the extended degree of wheat expansion creates the water assimilation of the expanded component weight of the batters; improved mixture tenacity decreases mixing resilience, consistency of the mixture, and extensibility (Sivam, et al., 2010). It is understood that the preparation and treatment of good debris content due to wheat is gradually problematic and that an increasingly full knowledge of the effect of whole wheat materials, such as wheat on mixture rheology, would enable oat researchers to comprehend the wellspring of the challenges (Peressini \& Sensidoni, 2009; Miller \& Hoseney, 1999). According to its review report, it helps to explain how the chemical-compatible properties of dough operate to generate and which types of factors affect dough development and retain gluten-framing proteins. Additionally, the findings could be helpful to determine the quality of various wheat-based products sold in various food markets, and to elucidate various health claims for diabetic patients (Khan et al., 2020a; Khan et al., 2020b).

\section{Dough development}

\subsection{Preparation of dietary fibre from wheat bran}

A sieve was used to pulverise wheat bran into particles of around $400 \mathrm{~mL}$. Then, in a colloid mill, $100 \mathrm{~g}$ of wheat bran powder was combined with $900 \mathrm{~mL}$ of distilled water. The carbohydrate fraction and water soluble dietary fibre were removed from the suspension by washing it under running water. After that, $900 \mathrm{~mL}$ distilled water was added, and the suspension was heated at $90{ }^{\circ} \mathrm{C}$ for 35 minutes before the $\mathrm{pH}$ was adjusted to 5.8 .

\subsection{Gluten wheat preparation}

It simply contains wheat gluten, whereas the fixed weight ratio of wheat gluten and wheat bran is higher. The two systems were designed to determine the differences between gluten dough and starch-gluten dough. In terms of gluten weight, contents were on the same moisture basis. Using a pin mixer, the ingredients were mixed and kneaded into a dough. In the following studies, samples of the resulting dough were utilized.

\subsection{Development of dough}

Wheat contains a perplexing blend of proteins that have the one kind of property of having the option of framing a viscoelastic batter when flour is blended in with water (Han et al., 2018a). Different mixture shapes are made out of a system of enormous protein atoms that encompass the starch granules and other flour parts (Han, et al., 2018a; Bakke \& Vickers, 2007). At the point when the starch and the water-dissolvable proteins (albumins and globulins) are cleaned out of a mixture, the water-insoluble protein portions (gliadin and glutenin proteins) stay in the viscoelastic mass called gluten (Han, et al., 2018b). The mixture alludes to a wet mass-created in the wake of the blending of wheat flour, water, and different fixings because of changes in the synthetic structure (Autio et al., 2001). When the mixture is blended or worked, the hydrated adaptable proteins are extended and adjusted toward massaging, giving more chances to frame cross-connects between the proteins, and working additionally incorporates air, which helps with the formation of solid disulfide bonds (He \& Hoseney, 1991; Lafiandra \& MacRitchie, 1997). As working proceeds, the protein systems join together to form sheets of proteins. The ionic collaboration that is created between the two protein parts is a result of di-sulfide linkages (by amino corrosive cysteine) (Shewry \& Tatham, 1997; Kaufman et al., 1986). While gluten is significant in making an extensible system, dissolvable proteins in the batter alcohol may also contribute to gas maintenance by shaping an impenetrable covering layer inside cells, successfully blocking pin-openings in cell dividers (Bock \& Damodaran, 2012). Physico-substance properties of the mixture assume a significant job in the bread kitchen, pasta, and prepared to-eat oats handling industries (Curti et al., 2015). The batter is created because of complex co-operations among wheat constituents during the blending activity. The procedure of mixture improvement starts with the expansion of water and the initiation of blending activity and all fixings are hydrated and seem like clingy glue (Bosmans et al., 2013). On further blending, the thickness increments, the clingy attributes of the mixture vanish and a non-clingy mass is created at the top consistency (Faubion \& Hoseney, 1997). At this stage, the material carries on like a viscoelastic mass with both flexible and extensible attributes. The point is to achieve improvements in the physical properties of the mixture during the time spent making the mixture, particularly bread batter, to enhance its capacity to retain the carbon dioxide gas delivered during yeast aging (Caballero et al., 2007). This improvement in gas maintenance capacity is especially significant when the mixture pieces arrive at the preparing stove.

In the beginning times of heating the yeast, the action is at its most prominent, and an enormous volume of carbon dioxide gas is created and discharged from the arrangement in the fluid period of the mixture (Caballero et al., 2007; Campbell et al., 2008). The mixture pieces grow gigantically as of now and a well-created or gluten structure is fundamental to withstand the inward weight of the extending mixture. The physicochemical properties of a blend of exceptional breads concern that allows the method to combine distortion resistance, extensibility, flexibility, and tenacity (Finney, 1984; Ahmed, 2014; Campbell, 2003). To understand the first three of these properties, consider the case of an elastic band (Faubion \& Hoseney, 1997). At the point when the elastic band is extended between our fingers, a level of power is required to change its shape as it opposes distortion (Gelinas \& McKinnon, 2004). If a low power is applied and one end of the band is discharged, it returns to its original position and mirrors the flexible properties (Bechtel et al., 2009). On the off chance that the elastic band is extended past the farthest point, it will, in the end, arrive at a point of augmentation and at last break, which is taken as a proportion of its extensibility (Gras et al., 2000).

The fourth physical property, tenacity, is plain as day, for example, anything that adheres to a surface has tenacity. Along these lines, advancement is seen as the adjustment of some 
significant physical properties of the bread mixture, which make significant commitments to the character of the last item.

This change in gluten structure can be accomplished by various diverse physical and synthetic procedures, and different blends of these structures are the premise of the various gatherings of bread-production forms that are in like manner used (Faubion \& Hoseney, 1997). The gliadin proteins of gluten are a gathering of monomeric proteins that comprise single-chain polypeptides that contain intrapolypeptide disulfide bonds (Ahmed, 2014; Kaufman et al., 1986). Gliadins carry on chiefly as a thick fluid when hydrated and confer extensibility permitting the mixture to ascend during aging while glutenin gives flexibility and quality (Han et al., 2018b) as shown in Figure 1.

\section{Wheat bran extensional qualities}

The extension and extensibility suggesting that the gluten ratio has a significant impact on the dough's tensile resistance. The larger the gluten ratio, the higher the force required to fracture the dough structure, as per the findings about the flexural viscosity of gluten-starch blends with varying gluten content.

\section{Typical pH values of bakery items of various kinds}

The perfect $\mathrm{pH}$ for gluten improvement is 5-6. It is an important key for different types of food industries and chemical industries which can influence many aspects of the processing, as well as shelf life and quality (Vemulapalli \& Hoseney, 1998). $\mathrm{pH}$ of some valuable bakery products are listed in Table 1.

\section{Factors affecting gluten network}

\subsection{Salt}

Bread mixture contains $1.5-2.0 \%$ salt by weight of flour (Beck et al., 2012). Salt eases back the catalyst action and the

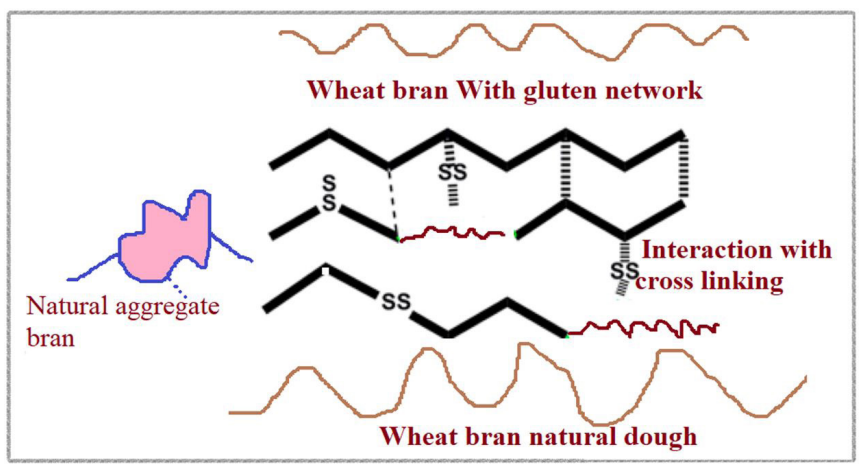

Figure 1. Schematic representation of the variable interaction of wheat bran with gluten network in doughs.

Table 1. $\mathrm{pH}$ of some valuable bakery products.

\begin{tabular}{cc}
\hline Product Name & pH Values \\
\hline Biscuits & $7.0-7.2$ \\
Soda crackers & $7.2-8.0$ \\
Baker's yeast bread & $5.3-5.8$ \\
Sourdough bread & $3.8-4.6$ \\
Wafer sheets & $6.8-7.4$ \\
\hline
\end{tabular}

pace of maturation. Salt fortifies gluten, delivering bread with higher volume and better morsels (Uthayakumaran et al., 2011).

\subsection{The assortment of wheat}

Different types of wheat flour contain different quantities of proteins and soft wheat contains fewer proteins (6-8\%), little amount of glutenin and amount of proteins, structures more fragile gluten (Goesaert et al., 2005; Kasarda, 1989).

Hard wheat contains a good quantity of protein (10-14\%), high gluten, a high amount of different proteins, good structure grounded, increasingly strong, flexible gluten (Kasarda, 1989). Fat: oil, emulsifiers, and sugars knead the mixture. Fat and emulsifiers coat proteins diminishing hydration and gluten improvement (like oil covering spaghetti).

\subsection{The measure of water}

Water absorption is basic for gluten development (Ablett et al., 1991). A small amount of water brings about less gluten improvement (lessens protein versatility). However, an excessive amount of water additionally decreases gluten advancement by weakening the proteins so much that their collaboration is limited (Ablett et al., 1991).

\subsection{Water hardness}

In hard water, $\mathrm{Ca}$ (calcium) and $\mathrm{Mg}$ (magnesium) fortify protein (gluten) (Slade \& Levine, 1993).

\subsection{Water $p H$}

The perfect $\mathrm{pH}$ for gluten improvement is 5-6. Above and underneath, $\mathrm{pH} 5-6$ lessens gluten quality, creating a progressively extensible (simpler to extend) batter (Holmes \& Hoseney, 1987). Preparing soft drinks raises $\mathrm{pH}$, resulting in more treat spread and increasingly permeable, delicate morsels.

\subsection{Raising}

Increasing air bubbles fortifies gluten, expanding cohesiveness, and versatility $\&$ better scrap (Lagrain et al., 2005).

\subsection{Chemicals}

Enzymes that separate proteins are normally present in flour, but latent when dry. Enzymes, yeast nutrients, minerals, salts, oxidants and reductants, bleaching agents, and emulsifiers can be used in dough conditioners. Chemicals separate gluten into little pieces so the batter becomes milder and progressively extensible (Vemulapalli \& Hoseney, 1998). The procedure known as autolyze (resting mixture for 15-30 minutes) permits time for proteins to stall gluten to create a progressively extensible batter, giving more volume and open morsels (Veraverbeke et al., 1998).

\section{Conclusion}

Gluten is a major source of protein that is also found in other varieties of wheat and other wheat and rice products that are most important for the bread-making process. Think of 
gluten as the miraculous net binding bread together; it makes dough grow through fermentation by catching gas bubbles and giving bread its distinctive texture. Many scientists explore the fact that gluten is important for dough formation. When two proteins, glutenin and glaidin, are mixed together with water, then gluten formation starts. So the gluten quantities are the most important for dough formation. Some important factors which influence gluten development are the variety of flour and mixing ingredients (salt, water $\mathrm{pH}$, wheat types, chemicals, etc.). Generally speaking, bread bakers shoot for an $11-13 \%$ level of protein, which gives a loaf good volume and texture. The present study was based on optimization and evaluation of the incorporation of each functional ingredient, including millets, legumes, and fruit, into the quality characteristics of yeast-leavened bread. The salient findings of this investigation are presented. It appears that the addition of functional ingredient flour to wheat flour modifies the rheological properties of the dough (creates dough with lower strength and inextensible texture) as well as the characteristics of the produced bread. The result confirmed that the strength of the wheat bran network with gluten formation was greater than the control dough and was employed for further analysis to remove the impacts of gluten network formation on the farinographic features and quality of dough. Overall, the dynamic rheological properties of wheat bran with a gluten network were investigated, while distinct viscoelastic characteristics were identified among them. The contribution of the water-binding activity and the steric effect of wheat bran were evaluated in this analysis by integrating normal and poor water-binding bran particles of various sizes into bread production. (Yano, 2019).

\section{Conflict of interest}

This article does not contain any studies with human or animal subjects.

\section{Funding}

This work was funded by the Deanship of Scientific Research at Princess Nourah bint Abdulrahman University, Riyadh, Saudi Arabia through the Research Groups Program Grant no. RGP-1440-0021.

\section{Acknowledgements}

This work was funded by the Deanship of Scientific Research at Princess Nourah bint Abdulrahman University, Riyadh, Saudi Arabia through the Research Groups Program Grant no. RGP1440-0021. The authors would like to especially thank Dr. Vasudha Sharma (Assistant Professor) of the Dept. of Food-Technology, Jamia Hamdard University in New Delhi.

\section{References}

Ablett, S., Darke, A. H., \& Lillford, P. (1991). The effect of mechanical deformation on the movement of water in foods. In H. Levine \& L. Slade (Eds.), Water relationships in foods, 302, (pp. 453-463). Boston: Springer. http://dx.doi.org/10.1007/978-1-4899-0664-9_24.

Ahmed, J. (2014). Effect of particle size and temperature on rheology and creep behavior of barley $\beta$-D-glucan concentrate dough.
Carbohydrate Polymers, 111, 89-100. http://dx.doi.org/10.1016/j. carbpol.2014.03.098. PMid:25037333.

Alashbayeva, L., Shansharova, D., Mynbayeva, A., Borankulova, A., \& Soltybayeva, B. (2021). Development of technology for bakery products. Food Science and Technology, 41(3), 775-781. http://dx.doi. org/10.1590/fst.61120.

Amirkaveei, S. H., Shahedi, M., Kabir, G. H., \& Kadivar, M. (2009). Effects of treated and untreated bran in dough dynamic rheology. International Journal of Food Science and Nutrition, 60(Suppl. 1), 190-198. PMid:19462327.

Autio, K., Flander, L., Kinnunen, A., \& Heinonen, R. (2001). Bread quality relationship with rheological measurements of wheat flour dough. Cereal Chemistry, 78(6), 654-657. http://dx.doi.org/10.1094/ CCHEM.2001.78.6.654.

Bakke, A., \& Vickers, Z. (2007). Consumer liking of refined and whole wheat breads. Journal of Food Science, 72(7), S473-S480. http://dx.doi. org/10.1111/j.1750-3841.2007.00440.x. PMid:17995660.

Bechtel, D. B., Abecassis, J., Shewry, P. R., \& Evers, A. D. (2009). Development, structure, and mechanical properties of the wheat grain. In K. Khan \& P.R. Shewry (Eds.), Wheat chemistry and technology (4th ed., pp. 19-49). St. Paul: AACC International. http:// dx.doi.org/10.1094/9781891127557.003.

Beck, M., Jekle, M., \& Becker, T. (2012). Impact of sodium chloride on wheat flour dough for yeast-leavened products. I. Rheological attributes. Journal of the Science of Food and Agriculture, 92(3), 585592. http://dx.doi.org/10.1002/jsfa.4612. PMid:21953245.

Bock, J. E., \& Damodaran, S. (2012). Bran-induced changes in water structure and gluten conformation in model gluten dough studied by Fourier transform infrared spectroscopy. Food Hydrocolloids, 3, 146-155.

Bosmans, G. M., Lagrain, B., Ooms, N., Fierens, E., \& Delcour, J. A. (2013). Biopolymer interactions, water dynamics, and bread crumb firming. Journal of Agricultural and Food Chemistry, 61(19), 46464654. http://dx.doi.org/10.1021/jf4010466. PMid:23631677.

Caballero, P. A., Gomez, M., \& Rosell, C. M. (2007). Improvement of dough rheology, bread quality and bread shelf life by enzymes combination. Journal of Food Engineering, 81(1), 42-53. http://dx.doi. org/10.1016/j.jfoodeng.2006.10.007.

Campbell, G. M. (2003). Bread aeration. In S. Cauvain (Ed.), Breadmaking: improving quality (pp. 352-374). Cambridge: Woodhead Publishing. http://dx.doi.org/10.1201/9780203495001.ch17.

Campbell, G. M. (2007). Roller milling of wheat. In Handbook of powder technology (Vol. 12, pp. 383-419). Oxford: Elsevier.

Campbell, G. M., Ross, M., \& Motoi, L. (2008). Bran in bread: effects of particle size and level of wheat and oat bran on mixing, proving and baking. In: G. M. Campbell, M. G. Scanlon \& D. L. Pyle (Eds.), Bubbles in food 2: novelty, health and luxury (pp. 337-354). St. Paul: Eagan Press. p 439. http://dx.doi.org/10.1016/B978-1-891127-59-5.50037-7.

Chaplin, M. F. (2003). Fiber and water binding. The Proceedings of the Nutrition Society, 62(1), 223-227. http://dx.doi.org/10.1079/ PNS2002203. PMid:12756971.

Curti, E., Carini, E., Tribuzio, G., \& Vittadini, E. (2015). Effect of bran on bread staling: physico-chemical characterization and molecular mobility. Journal of Cereal Science, 65, 25-30. http:// dx.doi.org/10.1016/j.jcs.2015.06.002.

Faubion, J. M., \& Hoseney, R. C. (1997). The viscoelastic properties of wheat flour doughs. In: H. Faridi \& J. M. Faubion (Eds.), Dough rheology and baked product texture (pp: 29-63). Huston: CBS press.

Finney, K. (1984). An optimized, straight-dough, bread-making method after 44 years. Cereal Chemistry, 61, 20-27. 
Gelinas, P., \& McKinnon, C. M. (2004). Effect of flour heating on dough rheology. Lebensmittel-Wissenschaft + Technologie, 37(1), 129-131. http://dx.doi.org/10.1016/S0023-6438(03)00117-8.

Goesaert, H., Brijs, K., Veraverbeke, W. S., Courtin, C. M., Gebruers, K., \& Delcour, J. A. (2005). Wheat flour constituents: how they impact bread quality, and how to impact their functionality. Trends in Food Science \& Technology, 16(1-3), 12-30. http://dx.doi.org/10.1016/j. tifs.2004.02.011.

Gras, P. W., Carpenter, H. C., \& Anderssen, R. S. (2000). Modeling the developmental rheology of wheat flour dough using extension tests. Journal of Cereal Science, 31(1), 1-13. http://dx.doi.org/10.1006/ jcrs.1999.0293.

Han, W., Ma, S., Li, L., Zheng, X., \& Wang, X. (2018a). Influence of wheat starch on the structural changes and size distribution of gluten induced by adding wheat bran dietary fiber. Stärke, 70(9-10), 1700302. http://dx.doi.org/10.1002/star.201700302.

Han, W., Ma, S., Li, L., Zheng, X., \& Wang, X. (2018b). Rheological properties of gluten and gluten-starch model doughs containing wheat bran dietary fiber. International Journal of Food Science \& Technology, 53(12), 2650-2656. http://dx.doi.org/10.1111/ijfs.13861.

He, H., \& Hoseney, R. C. (1991). Gas retention of different cereal flours. Cereal Chemistry, 68, 334-336.

Hemdane, S., Langenaeken, N. A., Jacobs, P. J., Verspreet, J., Delcour, J. A., \& Courtin, C. M. (2018). Study of the role of bran water binding and the steric hindrance by bran in straight dough bread making. Food Chemistry, 253, 262-268. http://dx.doi.org/10.1016/j. foodchem.2018.01.152. PMid:29502830.

Holmes, J. T., \& Hoseney, R. C. (1987). Chemical levening: Effect of $\mathrm{pH}$ and certain ions on bread making properties. Cereal Chemistry, 64, 343-348.

Kasarda, D. D. (1989). Glutenin structure in relation to wheat quality. In Y. Pomeranz (Ed.), Wheat is unique: structure, composition, processing, end-use properties, and products (pp. 227-302). St. Paul: AACC.

Kaufman, S. P., Hoseney, R. C., \& Fennema, O. (1986). Dough rheology-a review of structural models and the role of disulphide interchange reactions. Cereal Foods World, 31, 820-824.

Khan, F. A., Ameer, K., Qaiser, M. A., Pasha, I., Mahmood, Q., Anjum, F. M., Riaz, A., \& Amir, R. M. (2020a). Development and analysis of bread fortified with calcium extracted from chicken eggshells of Pakistani market. Food Science and Technology, 41(Suppl. 1), 14-20. http://dx.doi.org/10.1590/fst.07220.

Khan, M. A., Amir, R. M., Ameer, K., Rakha, A., Faiz, F., Hayat, I., Nadeem, M., Ahmed, Z., Riaz, A., \& Ashraf, I. (2020b). Characterization of oat bran $\beta$-glucan with special reference to efficacy study to elucidate its health claims for diabetic patients. Food Science and Technology, 41(1), 105-112. http://dx.doi.org/10.1590/fst.39019.

Lafiandra, D., \& MacRitchie, F. (1997). Structure function relationships of wheat proteins. In S. Damodaran \& A. Paraf (Eds.), Food proteins and their applications (pp. 293-324). New York: Marcel Dekker.
Lagrain, B., Brijs, K., Veraverbeke, W. S., \& Delcour, J. A. (2005). The impact of heating and cooling on the physicochemical properties of wheat gluten-water suspensions. Journal of Cereal Science, 42(3), 327-333. http://dx.doi.org/10.1016/j.jcs.2005.06.005.

Ma, F., Lee, Y. Y., \& Baik, B. (2018). Bran characteristics influencing quality attributes of whole wheat chinese steamed bread. Journal of Cereal Science, 79, 431-439. http://dx.doi.org/10.1016/j.jcs.2017.12.005.

Miller, K. A., \& Hoseney, R. C. (1999). Dynamic rheological properties of wheat starch gluten doughs. Cereal Chemistry, 76(1), 105-109. http://dx.doi.org/10.1094/CCHEM.1999.76.1.105.

Peressini, D., \& Sensidoni, A. (2009). Effect of soluble dietary fibre addition on rheological and breadmaking properties of wheat doughs. Journal of Cereal Science, 49(2), 190-201. http://dx.doi. org/10.1016/j.jcs.2008.09.007.

Benam, N. S., Goli, M., Ardebili, S. M. S., \& Vaezshoushtari, N. (2021). The quality characteristics of dough and toast bread prepared with wheat flour containing different levels of Portulaca oleracea leaf powder. Food Science and Technology. http://dx.doi.org/10.1590/fst.60820.

Shewry, P. R. (2009). Wheat. Journal of Experimental Botany, 60(6), 1537-1553. http://dx.doi.org/10.1093/jxb/erp058. PMid:19386614.

Shewry, P. R., \& Tatham, A. S. (1997). Disulphide bonds in wheat gluten proteins. Journal of Cereal Science, 25(3), 207-227. http://dx.doi. org/10.1006/jcrs.1996.0100.

Sivam, A. S., Sun-Waterhouse, D., Quek, S. Y., \& Perera, C. O. (2010). Properties of bread dough with added fiber polysaccharides and phenolic antioxidants: a review. Journal of Food Science, 75(8), R163-R174. http://dx.doi.org/10.1111/j.1750-3841.2010.01815.x. PMid:21535512.

Slade, L., \& Levine, H. (1993). Water relationships in starch transitions. Carbohydrate Polymers, 21(2-3), 105-131. http://dx.doi.org/10.1016/01448617(93)90006-P.

Sliwinski, E. L., Kolster, P., Prins, A., \& Vilet, T. (2004). On the relationship between gluten protein composition of wheat flours and large-deformation properties of their doughs. Journal of Cereal Science, 39(2), 247-264. http://dx.doi.org/10.1016/j.jcs.2003.10.006.

Uthayakumaran, S., Batey, I. L., Day, L., \& Wrigley, C. W. (2011). Salt reduction in wheatbased foods e technical challenges and opportunities. Food Australia, 63, 137-140.

Vemulapalli, V., \& Hoseney, R. C. (1998). Glucose oxidase effects on gluten and water solubles. Cereal Chemistry, 75(6), 859-862. http:// dx.doi.org/10.1094/CCHEM.1998.75.6.859.

Veraverbeke, W. S., Verbruggen, I. M., \& Delcour, J. A. (1998). Effects of increased high molecular weight glutenin subunits content of flour on dough mixing behavior and breadmaking. Journal of Agricultural and Food Chemistry, 46(12), 4830-4835. http://dx.doi. org/10.1021/jf980636y.

Yano, H. (2019). Recent practical researches in the development of gluten-free breads. NPJ Science of Food, 3, 7. http://dx.doi.org/10.1038/ s41538-019-0040-1. PMid:31304279. 